\title{
Ekonomi Dan Penguasa (Pemikiran Ibn Taimiyah tentang Mekanisme Pasar)
}

\author{
Syarial Dedi \\ Institut Agama Islam Negeri Curup \\ dedisyabrial@yahoo.co.id
}

\begin{abstract}
The classical scholars are not only focus on the issue of ritual worship, but also pay attention to the economic problems of society and even indicated theories of modern conventional economics is the adoption of the results of their thinking. One of them is Ibn Taymiyyah. Its has inspired the market mechanism. Prices are handed over to businesses naturally, without being interfered with by the government. On the other hand religion gives authority to the government that must be obeyed by the ruler in taking care of them. This study uses the method of literature with the conclusion that in the free market, the price is considered by the strength of supply and demand. Free market runs fair, reasonable, likes the same likes and no distortion. However, the market mechanism is not always running perfectly, often distortion occurs. In this condition, the state's role as the supervisor of development morality is needed to make people aware that moral norms and ethical values are very important as the principle of development that must be implemented in the life of the economy. This means that Ibn Taymiyya'bs economic thought is in line with the duties and authorities of the ruler.
\end{abstract}

Keywords: Ibn Taimiyah, Market, Demand, Supply, Price and Goverment.

\begin{abstract}
Abstrak
Para ulama klasik tidak hanya berkutat sebatas persoalan ibadah ritual saja, tetapi juga menaruh perhatian pada masalah perekonomian masyarakat bahkan diindikasikan teori-teori ekonomi konvensional modern merupakan adopsi dari hasil pemikiran mereka. Salah satu dari mereka adalah Ibn Taimiyah. Ia telah memberikan inspirasi tentang bagaimana persoalan mekanisme pasar. Harga diserahkan pada pelaku bisnis secara alami, tanpa dicampuri oleh pemerintah. Di sisi lain agama memberikan kewenangan kepada pemerintah yang harus ditaati oleh rahyat dalam mengurus mereka. Penelitian ini menggunakan metode kapustakaan dengan kesimpulan bahwa dalam pasar bebas, harga dipertimbangkan oleh kekuatan penawaran dan permintaan. Pasar bebas berjalan fair, wajar, suka sama suka dan tidak ada distorsi. Namun, mekanisme pasar
\end{abstract}

Al Falah: Journal of Islamic Economics, Vol. 3, No. 1, 2018

STAIN Curup|E-ISSN: 2548-3102, P-ISSN: 2548-2343

Available online: http://journal.staincurup.ac.id/index.php/alfalah 
tidak selamanya berjalan sempurna, seringkali terjadi distorsi. Dalam kondisi ini dituntut peran negara sebagai supervisor moralitas pembangunan guna menyadarkan masyarakat bahwa norma moral dan nilai etika sangat penting sebagai asas pembangunan yang mesti diinplementasikan dalam kehidupan perekonomian. Ini artinya pemikiran ekonomi Ibn Taimiyah sejalan dengan tugas dan kewenangan penguasa.

Kata Kunci: Ibn Taimiyah, pasar, permintaan, penawaran, harga, penguasa

\section{PENDAHULUAN}

Salah seorang ilmuan Barat bernama Schumpeter dalam thesisnya yang terkenal "Great Gap atau Blank Centuries" berusaha menafikan keberadaan dan kontribusi ilmuan muslim dalam sejarah perkembangan pemikiran ilmu ekonomi. Begitupun dalam bukunya, History of Economic Analysis. ${ }^{1}$ Sama halnya dengan Adam Smith yang disebut oleh kalangan Ilmuan Barat sebagai "the father of economic science" hanya mengemukakan konsep dasar ekonomi dalam bentuk pemikiran seperti dalam bukunya The Wealth of Nation yang melahirkan istilah "Invisible Hand" yang kemudian dikembangkan ilmuan-ilmuan ekonomi berikutnya menjadi konsep pasar bebas dan hukum pasar supply-demand. Sedangkan ide tentang pasar supply dan demand sudah dikemukakan oleh ilmuan Muslim jauh sebelum Adam Smith dilahirkan. ${ }^{2}$ Bedanya cuma satu, Adam Smith diakui sebagai "Bapak ilmu ekonomi" oleh para ilmuan ekonomi Barat tapi ilmuan Muslim tidak dianggap pernah memiliki pemikiran ekonomi.

Banyak ilmuan Muslim yang sudah mengemukakan berbagai pemikiran ekonomi sebelum berkembang menjadi teori ekonomi modern saat ini, namun tak ditemukan dalam literatur sejarah pemikiran ekonomi yang ditulis oleh ilmuan-ilmuan Barat.

Salah satu ilmuan Muslim yang pemikirannya berusaha dinafikan oleh Schumpeter dalam sejarah perkembangan pemikiran ilmu ekonomi adalah Ibn Taimiyah. Penciplakan pemikiran ekonomi Ibn Taimiyah dengan cara yang tidak ilmiah ini, sangat merugikan umat muslim. Padahal umat Islam masa kini sangat membutuhkan pandangan ekonomi yang jernih tentang apa yang diharapkan dan bagaimana sesuatu itu bisa dilakukan.

Ibn Taimiyah merupakan salah seorang ilmuan Muslim yang secara mendetail membahas tentang mekanisme pasar dan jenis-jenis pasar. Menurut

1http:/ /www.hidayatullah.com/artikel/tsaqafah/read/2010/09/22/1309/hargapasar-menurut-ibnu-taimiyyah. html. (diakses tanggal 21 April 2017)

2http:/ /www.hidayatullah.com/artikel/tsaqafah/read/2010/09/22/1309/hargapasar-menurut-ibnu-taimiyyah.html (diakses tanggal 21 Apri 2017) 
pemikiran Ibn Taimiyah, bahwa terjadinya fluktuasi harga pasar dipengaruhi oleh permintaan dan ketersediaan barang; harga akan naik jika penawaran meningkat sementara persediaan menipis, begitupun sebaliknya. Hal ini sudah merupakan hukum alam, yang disebut dengan mekanisme pasar. Pemerintah tidak dibenarkan untuk ikut campur. Teori inilah yang diistilahkan oleh ekonomi Barat dengan 'supply dan demand. Namun, di sisi lain pemerintah selaku penguasa diberi tugas dan wewenang mengurus rakyatnya. Dal hal ini keikutsertaan pemerintah tidak dapat dielakkan. Rakyat bahkan diwajibkan untuk mentaati perintah penguasa.

Artikel ini dimaksudkan untuk menelusuri pemikiran ekonomi Ibn Taimiyah berkenaan dengan mekanisme pasar serta kaitannya dengan kewenangan penguasa. Kontribusi nyata dalam tulisan ini adalah memberikan gambaran konsep yang jelas dan orisinil dari pemikiran Ibn Taimiyah tentang mekanisme pasar, karena dirujuk langsung pada kitab aslinya. Kemudian konsep tersebut dapat dipergunakan sebagai analisis untuk menilai keterlibatan pemerintah terhadap mekanisme pasar, seperti penetapan harga sembako, penyamarataan harga Bahan Bakar Minyak (BBM) dan sebagainya.

Penelitian ini merupakan penelitian kepustakaan (library reseach) dengan pendekatan kualitatif. Proses penganalisaan akan dideskripsikan dengan menggunakan tekhnik content analysis (analisa isi).

\section{Profil Ibn Taimiyah}

Nama lengkapnya adalah Taqi al-Din Ahmad bin Abd al-Halim bin Abd Salam bin Taimiyah. Ia lahir di Harran 22 Januari 1263 M (10 Rabiul Awwal $661 \mathrm{H}){ }^{3}$ Ayahnya bernama Abd al-Halim, pamannya Fakhruddin dan kakeknya Majduddin merupakan ulama besar dari mazhab Hambali dan menulis sejumlah buku. ${ }^{4}$

Ia dan keluarganya mengungsi ke Damaskus untuk menghindari serbuan tentara Tartar dari suku Mongol sekitar tahun 1268 M, pada waktu itu ia hampir berusia enam tahun. Pada tahun $1282 \mathrm{M}$ ketika ayahnya meninggal, Ibn Taimiyah menggantikan kedudukan ayahnya sebagai Guru Besar Hukum Hambali

${ }^{3}$ Euis Amalia. Sejarah Pemikiran Ekonomi Islam. (Jakarta: Grama Publishing, 1996), h.206.

${ }^{4}$ Adiwarman Azwar Karim, Sejarah Pemikiran Ekonomi Islam, (Jakarta: PT. Raja Grafindo Persada, 2006), h.351. 
dan memangku jabatan ini selama 17 tahun. $^{5}$ Agaknya ada pengaruh keluarganya, sehingga kemudian Ibn Taimiyah bermazhabkan Hambaliyah. ${ }^{6}$

Semasa kecilnya Ibn Taimiyah banyak belajar kepada para ulama terkemuka. Jumlah gurunya mencapai 200 orang, di antaranya adalah Syamsudin al-Maqdisi, Ibn al-Yusr, al-Kamal bin Abd Majid, Yahya bin al-Shairafi, Ahmad bin Abu al-Khair dan lainnya. ${ }^{7}$ Sehingga mengantarkan beliau menjadi ahli dalam tafsir, hadis, fiqh, matematika dan filsafat dalam usia masih belasan tahun.

Ibn Taimiyah hidup pada zaman pemerintahan Bani Mamluk. Pada saat itu harga-harga barang ditetapkan dalam Dirham, yaitu mata uang peninggalan Bani Ayyubi. Karena desakan kebutuhan masyarakat terhadap mata uang dengan pecahan lebih kecil, maka Sultan Kamil Ayyubi memperkenalkan mata uang baru yang berasal dari tembaga yang disebut dengan Fulus. Dirham ditetapkan sebagai alat transaksi besar, dan Fulus digunakan untuk transaksi-transaksi dalam nilai kecil. Inilah kemudian menginspirasi pemerintahan Sultan Kitbugha dan Sultan Dzahir Barquq untuk mencetak Fulus dalam jumlah sangat besar dengan nilai nominal yang melebihi kandungan tembaganya (intrinsic value). Akibatnya kondisi perekonomian semakin memburuk, karena nilai mata uang menjadi turun. $^{8}$ Kondisi pasar tidak stabil, kenaikan harga terjadi akibat ketidakadilan atau malpraktek dari para penjual, terjadinya monopoli dan kezaliman. Hal ini terindikasi dari kata yang digunakan Ibn Taimiyah adalah zulm, yang berarti pelanggaran hukum atau ketidakadilan.

Melihat kondis itu, sebagai seorang ilmuan, Ibn Taimiyah terpanggil dan bahkan diminta oleh penguasa untuk mencarikan solusinya. Solusi cemerlang dari Ibn Taimiyah tersebut tertuang dalam dalam Majmu' Fatawa Syaikh al-Islam, as-Siyasah asy-Syar'iyyah fi Ishlah ar-Ra'i wa ar-Ra'iyah, serta al-Hasbah fi al-Islam.'

${ }^{5}$ Nur Chamid, Jejak Langkah Sejarah Pemikiran Ekonomi Islam, (Yogyakarta: Pustaka Pelajar, 2010), Cet ke-1, h.230.

'Abdulah Mustofa al-Maraghi, Pakar-pakar Figh Sepanjang Sejarah, penerjemah Husein Muhammad, judul asli "Fath al-Mubin fi Tabaqat al-Usuliyyin", (Yogyakarta: LKPSM, 2001), h.237.

7Boedi Abdullah, Peradaban Pemikiran Ekonomi Islam, (Bandung: Pustaka Setia, 2010), h.250.

${ }^{8}$ Nur, Jejak Langkah, h.240.

${ }^{9}$ Nur, Jejak Langkah, h.230. Di samping sebagai seorang ilmuan, Ibn Taimiyah juga dikenal sebagai tokoh pembaharu dalam artian memurnikan ajaran Islam agar tidak tercampur dengan hal yang berbau bid'ah. Di antara elemen gerakan reformasinya adalah; Pertama, melakukan reformasi melawan praktek-praktek yang tidak Islami. Kedua, kembali ke arah prioritas fundamental ajaran Islam dan semangat keagamaan yang murni, sebaliknya memperdebatkan ajaran yang tidak fundamental dan sekunder. Ketiga, berbuat untuk kebaikan publik melalui intervensi pemerintah dalam kehidupan 
Sampai sekarang pemikiran ekonomi Ibn Taimiyah masih relevan untuk dikaji dan diterapkan.

Ibn Taimiyah meninggal dunia di Damaskus tahun $728 \mathrm{H}$ dan dikebumikan di pemakaman kaum sufi. ${ }^{10}$

\section{Mekanisme Pasar Menurut Ibn Taimiyah}

Pasar dalam pengertian ilmu ekonomi adalah pertemuan antara permintaan dan penawaran. Dalam pengertian ini, pasar bersifat interaktif, bukan fisik. Adapun mekanisme pasar adalah proser penentuan tingkat harga berdasarkan kekuatan permintaan dan penawaran. Pertemuan antara permintaan (demand) dan penawaran (supply) dinamakan equilibrium price (harga seimbang). ${ }^{11}$

Ibn Taimiyah juga memiliki pandangan tentang pasar bebas, di dalam kitab Majmu' al-Fatawa, dia mengatakan:

$$
\begin{aligned}
& \text { أن الغلاء والرخص لا تنحصر أسبابه في ظلم بعض بل قد يكون سببه قلة ما يخلق أو } \\
& \text { يجلب من ذلك المال المطلوب فإذا كثرت الرغبات في الشيئ وقل المرغوب فيه ارتفع } \\
& \text { سعره فإذا كثر وقلت الرغبات فيه أنخفض سعره والقلة و الكثرة قد لا تكون بسبب } \\
& \text { من العباد وقد تكون بسبب لا ظلم فيه وقد تكون بسبب فيه ظلم والله تعالى يجعل } \\
& \text { الرغبات في القلوب } 12
\end{aligned}
$$

ekonomi, mendorong keadilan dan keamanan publik serta menjaga mereka dari sikap eksploitatif dan mementingkan diri sendiri. Lihat Euis, Sejarah Pemikiran, h.163-164.

${ }^{10} \mathrm{Al}$-Maraghi, Pakar-pakar, 240. Menurut Adiwarman, Ibn Taimiyah dia meninggal dunia di dalam tahanan pada tanggal 20 Dzul Qo'dah $728 \mathrm{H}$ bersamaan dengan 26 September $1328 \mathrm{M}$ setelah mengalami perlakuan yang sangat kasar selama lima bulan. Agaknya ini akibat dari penghormatan yang begitu besar diberikan masyarakat dan pemerintah kepada Ibn Taimiyah membuat sebagian orang merasa iri dan berusaha untuk menjatuhkan dirinya. Sejarah mencatat bahwa sepanjang hidupnya, Ibn Taimiyah telah menjalani masa tahanan sebanyak empat kali akibat fitnah yang dilontarkan para penentangnya. Lihat Adiwarman, Sejarah Pemikiran, h.330.

${ }^{11}$ Euis, Sejarah Pemikiran, 164. Islam tidak melarang pedagang mereup laba sebesar-besarnya dari usaha niaga yang dilakukan, selagi tidak melanggar hak-hak Allah dan tidak merugikan orang lain, baik individu maupun khalayak ramai. Lihat Usamah Abd Sami', al-Ihtikar fi Mizan asy-Syar'iyah al-Islamiyah, (Iskandariyah: Dar al-Jami'ah alJadidah, 2007), h.15.

12Taqi ad-Din Ahmad bin Taimiyah, Majmu' al-Fatawa, ([t.t]: Dar al-Wafa' lil Kiba'ah wa an-Nasyar wa at-Tauzi', 2001), Jilid 4, h.307. 
Naik turunnya barga tidak selalu disebabkan pada kezhbaliman sebagian orang. Kadang-kadang sebabnya adalah kekurangan dalam produksi atau penurunan impor dari barang-barang yang dibutubkan. Maka apabila kebutuban meningkat terhadap barang, dan menurunnya kemampuan menyediakannya, barga dengan sendirinya akan naik, jikea kemampuan penyediaan barang meningkat dan permintaan menurun, harga akan turun. Sedikit dan banyaknya barang tidak mesti diakibatkan oleh perbuatan seseorang. Bisa saja berkaitan dengan sebab yang tidak melibatkan ketidakadilan. Atau sesekali bisa juga disebabkan oleh ketidakadilan. Maha besar Allah, yang menciptakan kemanan pada hati manusia.

Dari unngkapan di atas dapat dipahami bahwa jika kebutuhan terhadap jumlah barang meningkat, sementara kemampuan menyediakannya menurun, harga dengan sendirinya akan naik. Di sisi lain, jika kemampuan penyediaan barang meningkat dan permintaan menurun, secara otomatis harga akan turun. Itulah hukum alam tentang pasar, suatu harga dipertimbangkan oleh kekuatan penawaran dan permintaan yang terjadi secara alami. Tetapi, Ibn Taimiyah juga tidak menampik adanya kelangkaan barang atau berlimpahnya persediaan barang bisa juga disebabkan oleh ketidakadilan.

Walaupun Ibn Taimiyah tidak pernah membaca Wealt of Nations karena ia hidup lima abad sebelum kelahiran Adam Smith, bapak teori ekonomi klasik yang menulis buku termasyhur itu. Namun, ketika masyarakat pada masanya beranggapan bahwa peningkatan harga merupakan akibat dari ketidakadilan dan tindakan melanggar hukum dari pihak penjual atau mungkin sebagai akibat manipulasi pasar, Ibn Taimiyah langsung membantahnya. Dengan tegas ia mengatakan bahwa harga ditentukan oleh kekuatan penawaran dan permintaan. ${ }^{13}$

Dari pernyatan di atas terdapat indikasi kenaikan harga yang terjadi disebabkan oleh perbuatan ketidakadilan atau zulm para penjual. Perbuatan ini disebut manipulasi yang mendorong terjadinya ketidak sempurnaan pasar. Tetapi pernyataan ini tidak bisa disamakan dalam segala kondisi, karena bisa saja alasan naik dan turunnya harga disebabkan oleh kekuatan pasar. ${ }^{14}$ Tampaknya ada kebiasaan yang terjadi di zaman Ibn Taimiyah, kenaikan harga terjadi akibat ketidakadilan atau malpraktek dari para penjual, sehingga istilah yang dipakai adalah zulm, yang berarti pelanggaran hukum atau ketidakadilan.

${ }^{13}$ Adiwarnan A.Karim, Ekonomi Islam Suatu Kajian Kontempor, Jakarta: Gema Insani, 2007), Cet ke-3, 160. Bandingkan dengan Heri Sudarsono, Konsep Ekonomi Islam, (Yogyakarta: Ekonisia, 2002), h.140.

${ }^{14}$ Euis, Sejarah Pemikiran, h.164-165. 
Ibn Taimiyah menyebutkan dua sumber persediaan, yakni produksi lokal dan impor barang-barang yang diminta, sebagimana bunyi pernyataannya:

$$
\text { ما يخلق أو يجلب من ذلك المال المطلوب15 - مات }
$$

Barang produksi atau impor dari barang-barang yang diminta

Untuk menggambarkan permintaan terhadap barang tertentu, ia menggunakan istilah raghbah fi al-syai yang berarti hasrat terhadap sesuatu, yakni barang. Hasrat merupakan salah satu faktor terpenting dalam permintaan, faktor lainnya adalah pendapatan yang tidak disebutkan oleh Ibn Taimiyah. Perubahan dalam supply digambarkannya sebagai kenaikan atau penurunan dalam persediaan barang-barang, yang disebabkan oleh dua faktor, yakni produksi lokal dan impor. $^{16}$

Pernyataan Ibn Taimiyah di atas menunjuk pada apa yang dikenal sekarang sebagai perubahan fungsi penawaran dan permintaan, yakni ketika terjadi peningkatan permintaan pada harga yang sama dan penurunan pada harga yang sama atau, sebaliknya, penurunan permintaan pada harga yang sama dan pertambahan persediaan pada harga yang sama. Apabila terjadi penurunan persediaan disertai dengan kenaikan permintaan, harga-harga dipastikan akan mengalami kenaikan, dan begitu pula sebaliknya. ${ }^{17}$

Namun demikian, kedua perubahan tersebut tidak selamanya beriringan. Ketika permintaan meningkat sementara persediaan tetap, harga-harga akan mengalami kenaikan. Ibn Taimiyah menjelaskan:

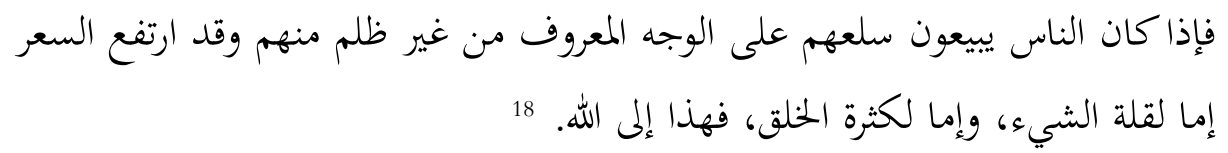

Apabila orang-orang menjual barang dagangannya dengan cara yang dapat diterima secara umum tanpa disertai dengan kezaliman dan harga-barga mengalami kenaikan sebagai konsekuensi dari penurunan jumlah barang (qillah al-syai), atau peningkatan jumlah penduduk (katsrah al-khalq), bal ini disebabkan oleh Allah SWT.

\footnotetext{
15Ibn Taimiyah, Majmu', Jilid 4, h.307.

16Adiwarman, Sjarah Pemikiran, h.364-365.

${ }^{17}$ Adiwarman, Sejarah Pemikiran, h.365.

${ }^{18}$ Taqi ad-Din Ahmad bin Taimiyah, al-Hisbah fi al-Islam, (Kairo: Dar Sya’b, 1976):
} h.22. 
Ungkapan Ibn Taimiyah di atas tampaknya menggambarkan perubahan secara terpisah. Penurunan barang dengan kata lain adalah jatuhya penawaran. Sedangkan meningkatnya penduduk akan menyebabkan terjadinya peningkatan permintaan, karena itu bisa dikatakan sebagai naiknya permintaan. Naiknya harga karena jatuhnya supply atau naiknya permintaan, dalam kasus itu dikarakteristikkan karena Allah SWT, mengindikasikan bahwa mekanisme pasar itu merupakan kondisi alamiah yang impersonal.

Ibn Taimiyah memberikan penjelasan yang rinci tentang beberapa faktor yang mempengaruhi permintaan dan tingkat harga. Berikut faktor-faktor tersebut: ${ }^{19}$

1. إذا عرف ذلك فرغبة الناس كثيرة الإختلاف والتنوع فإها تختلف بكثرة المطلوب وقلته فعند قلته يرغب فيه مالا يرغب عند الكثرة

Permintaan masyarakat (al-ragabah) yang sangat bervariasi (people's desire) terhadap barang. Faktor ini tergantung pada jumlab barang yang tersedia (almatlub). Suatu barang akan semakin disukai jika jumlabnya relatif kecil (scarce) daripada yang banyak.jumlahnya.

2. وبكثرة الطلاب وقلتهم فإن ما كثر طالبوه يرفع ثمنه بخلاف ما قل طالبوه

Tergantung kepada jumlab orang yang membutubkan barang (demander) consumer/ tullab). Semakin banyak jumlah peminatnya, semakin tinggi nilai suatu barang.

3. 3بحسب قلة الحاجة وكثرها وقوتا وضعفها فعند كثرة الحاجة وقوقا ترتفع القيمة ما لا ترتفع عند قلتها وضعفها

Harga juga dipengarubi oleh kuat lemabnya kebutuhan terhadap suatu barang, selain juga besar dan kecilnya permintaan. Jika kebutuhan terhadap suatu barang kuat dan berjumlah besar, maka harga akan naike lebih tinggi jike dibandingkan dengan jika kebutuhannya lemah dan sedikit.

19Ibn Taimiyah, Majmu', 2001, Jilid 15: 289. Untuk terjemahan bebasnya dikutip dari Munrokhim Misanan dkk., Text Book Ekonomi Islam, (Yogyakarta: Direktorat Perbankan Syariah Bank Indonesia DPbS BI \& Pusat Pengkajian dan Pengembangan Ekonomi Islam Universitas Islam Indonesia (P3EI UII), h.155-156. 
4. وبحسب المعاوض فإن كان مليا دينا يرغب في معاوضته بالثمن القليل الذى لا يبذل بمثله لمن يظن عجزه أو مطله أوجحده

Harga juga akan bervariasi menurut kualitas pembeli barang tersebut (al-mu'awid). Jika pembeli merupakan orang kaya dan terpercaya (kredibel) dalam membayar kewajibannya, maka kemungkinan ia akan memperoleb tingkat harga yang lebih rendah dibandingkan dengan orang yang tidak kredibel (suka menunda kewajiban atau mengingkarinya).

وبحسب العوض فقد يرخص فيه إذا كان بنقد رائج ما لا يرخص فيه إذا كان بنقد أخر 5 دونه في الرواج

Tingkat harga juga dipengarubi oleh jenis uang yang digunakan sebagai alat pembayaran. Jika menggunakan jenis mata uang yang umum dipakai, maka kemungkinan harga relatif lebih rendah jika dibandingakan dengan menggunakan mata uang yang tidak. umum atau kurang diterima secara luas.

6. وذلك أن المطلوب من العقود هو التقابض من الطرفين فإذا كان الباذل قادرا على التسليم موفيا بالعهد كان حصول المقصود بالعقد معه بخلاف ما إذا لم يكن تام القدرة أو تام الوفاء ومراتب القدرة والوفاء تختلف ... وهذا يكون في البائع وفي المشترى وفي المؤجر والمستأجر ...فإن المبيع قد يكون حاضر وقد وقد يكون غائب فسعر الحاضر أقل من سعر الغائب وكذلك المشترى قد يكون قادرا في الحال على الأداء لأن معه مالا وقدلا

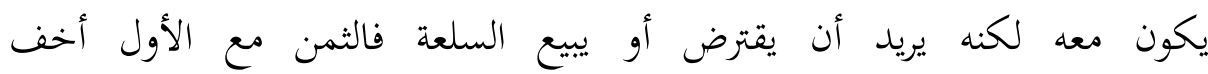

Hal di atas dapat terjadi karena tujuan dari suatu transaksi haruslah menguntungkan penjual dan pembeli. Jika pembeli memiliki kemampuan untuke membayar dan dapat memenubi semua janjinya, maka transaksi akan lebih mudah atau lancar dibandingkan dengan jika pembeli tidak memiliki kemampuan membayar dan mengingkari janjinya. Tingkat kemampuan dan kredibilitas pembeli berbedabeda. Hal ini berlaku bagi pembeli maupun penjualnya, penyewa dan yang menyewakan, dan siapa pun juga. Obyek dari suatu transaksi terkadang (secara fisike) nyata atau juga tidak nyata. Tingkat harga barang yang lebih nyata (secara 
fisik) akan lebih rendah dibandingkan dengan yang tidak nyata. Hal yang sama dapat diterapkan untuk pembeli yang kadang-kadang dapat membayar karena memiliki uang, tetapi kadang-kadang mereka tidak memiliki uang cash dan ingin meminjam. Harga pada kasus yang pertama kemungkinan lebib rendab daripada yang kedua.

7. وكذالك المؤجر قد يكون قادرا على تسليم المنفعة المستحقة بالعقد بكيث يستوفيها المستأجر بلا كلفة وقد لا يتمكن المستأجر من استيفاء المنفعة إلا بكلفة كالقرى التى ينتابها الظلمة من ذى سلطان أو لصوص أو تنتابها السباع فليست قيمتها كقيمة الأرض التى لا تحتاج إلى ذلك بل من العقار ما لا يمكن أن يستوف منفعته إلا ذو قدرة يدفع الضرر من منفعته لأعوانه وأنصاره أويستوفى غيره منه منفعة يسيرة وذو القدرة يستوف كمال منفعته لدفع الضرر عنه

Kasus yang sama dapat diterapkan pada orang yang menyewakan suatu barang. Kemungkinan ia berada pada posisi sedemikian rupa, sehingga penyewa dapat memperoleh manfaat dengan tanpa tambahan biaya apapun. Tetapi, kadang-kadang penyewa tidak dapat memperoleh manfaat ini jika tanpa tambahan biaya, seperti yang terjadi di desa yang dikuasai penindas atau oleb perampok, atau di suatu tempat diganggu oleh binatang-binatang pemangsa. Sebenarnya, harga sewa tanah seperti itu tidaklah sama dengan harga tanah yang tidak membutubkan biaya-biaya tambahan ini.

Adiwarman Karim dalam bukunya Ekononi Islam Suatu Kajian Kontemporer, dengan lugas mengatakan bahwa Ibn Taimiyah tidak pernah menggunakan istilah kompetisi (konsep yang muncul pada akhir evolusi pemikiran ekonomi) ataupun menjelaskan kondisi dari kompetisi sempurna dalam istilah kontemporer. Karena itu, menurut Adiwarman, Ibn Taimiyah kemudian menulis bahwa untuk memaksa orang agar menjual berbagai benda yang tidak diharuskan untuk menjualnya atau melarang mereka menjual benda-benda yang diperbolehkan untuk dijual, adalah tidak adil dan karenanya melanggar hukum. ${ }^{20}$

Dalam istilah kontemporer, hal ini secara jelas merujuk pada kebebasan penuh untuk masuk atau keluar pasar. Kebebasan transaksi dan adanya persaingan yang sempurna di pasar Islam tidak akan terwujud selama halangan-

${ }^{20}$ Adiwarnan A.Karim, Ekonomi Islam Suatu Kajian Kontempor, Jakarta: Gema Insani, 2007), Cet ke-3, 161. Pernyataan Ibn Taimiyah yang dipahami Adiwarman tersebut dapat dilihat dalam Ibn Taimiyah, al-Hisbah, 1976:20-26. 
halangan tidak dihilangkan dari orang-orang yang melakukan transaksi di pasar. Maka mereka masuk pasar dan ke luar dengan bebas, juga diberikan kebebasan mengangkut barang dari satu tempat ke tempat lain, dan memindahkan unsur produksi di antara bermacam-macam kegiatan ekonomi sesuai fluktuasi persediaan dan permintaan barang. Pasar tetap terbuka bagi semua orang yang bertransaksi di dalamnya.

Kebebasan untuk keluar masuk pasar tersebut juga sudah tergambar pada masa Umar, dia tidak membolehkan orang untuk membatasi setiap tempat di pasar, atau menguasai tempat tanpa memberi yang lain, tetapi membiarkan orang memilih tempatnya di pasar semala ia masih berjual beli. Apabila dia selesai, maka tempat tersebut untuk siapa yang dulu datang. Umar pernah berkata, "Pasar itu menganut ketentuan masjid, barangsiapa datang dahulu di satu tempat duduk, maka tempat itu untuknya sampai dia berdiri dari situ dan pulang ke rumahnya atau selesai jual belinya." Namun Umar sendiri memberikan pengecualian dalam beberapa cara dan strategi ketika kelihatan hal tersebut tidak baik, atau yang lain lebih baik darinya. ${ }^{21}$

Selanjutnya, Ibn Taimiyah mengkritik adanya kolusi antara pembeli dan penjual karena hal itu dapat menggagu kondisi alamiah pasar. Perbuatan tersebut jelas merupakan tindakan zhalim yang dilakakan oleh penjual dan pembeli, makanya harus diberantas sebisa mungkin, Ibn Taimiyah mengatakan:

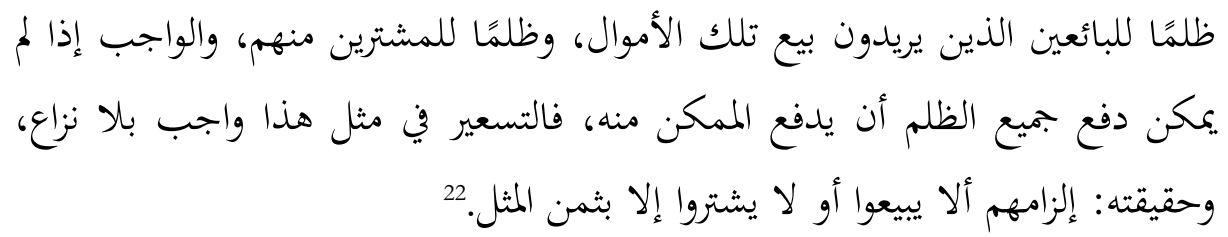

Suatu kezaliman dari para pedagang yang bermaksud menjual barang tersebut, dan suatu kerhaliman juga oleh para pembeli. Dan wajib apabila tidak mungkin menolak selurub bentuk kę̧aliman bahwa menolak apa yang mungkin darinya. Maka harga pantas (pasaran) dalam kasus ini adalab wajib dengan tanpa perbantahan, dan pada intinya; mestilah menjual atau tidak membeli kecenali sesuai dengan harga yang pantas (pasaran).

Ibn Taimiyah dengan tegas melarang praktek jual beli riba, mengandung unsur judi, gharar dan segala bentuk penipuan, larangan itu menurutnya sudah

${ }^{21}$ Jaribah bin Ahmad al-Haritsi, Fikih Ekonomi Umar bi Khathabia, penerjemah Asmuni Solihan Zamakhsyari, judul asli "Al-Fiqh al-Iqtishadi li Amiril Mukminin Umar bin Khaththab”, (Jakarta; Khalifa, 2006), Cet ke-1, h.601-602.

22Ibn Taimiyah, al-Hisbah, h.23. 
merupakan kesepakatan kaum muslim. Seperti pernyataanya Ibn Taimiyah berikut ini:

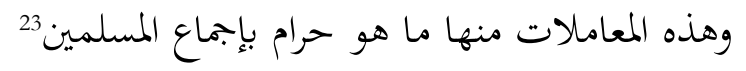

Dan ini semua bentuk-bentuk transaksi yang dibaramkan dengan kesepakatan orang muslim.

Ibn Taimiyah menentang peraturan yang berlebihan ketika kekuatan pasar secara bebas bekerja untuk menentukan harga yang kompetitif, karena hal itu merupakan tindakan haram yang dilakukan penguasa, sebagaimana dinyatakannya dengan tegas:

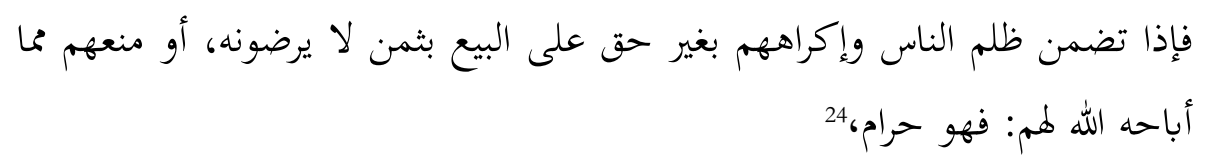

Maka apabila mengandung kezhaliman pada manusia dan memaksa mereka dengan tanpa hak untuk menjual dengan harga yang tidak mereka redhai atau melarang mereka menjual sesuatu yang dibolebkan tuhan; maka itu adalah perbuatan haram.

Dengan tetap memperhatikan kondisi pasar tidak sempurna, Ibn Taimiyah merekomendasikan bahwa bila penjual melakukan penimbunan dan menjual pada harga yang lebih tinggi dibandingkan dengan harga normal, padahal orangorang membutuhkan barang ini, maka para penjual diharuskan untuk menjualnya pada tingkat harga ekuivalen. Perbuatan itu harus dan bahkan wajib dilakukan penguasa sebagimana katanya:

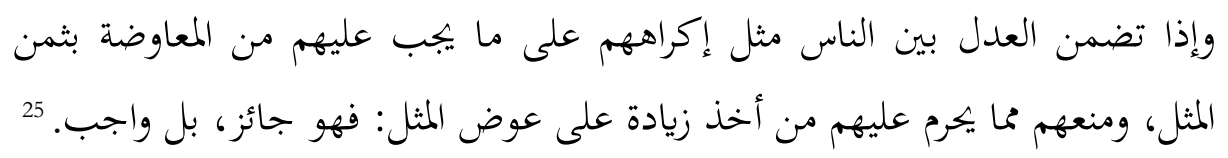

Dan apabila mengandung keadilan pada manusia adalah seumpama memaksa mereka atas apa yang wajib bagi mereka berupa ganti dengan harga yang sepantasnya, dan melarang mereka dari sesuatu yang diharamkan atas mereka yaitu mengambil

\footnotetext{
${ }^{23}$ Ibn Taimiyah, al-Hisbah, h.20.

${ }^{24}$ Ibn Taimiyah, al-Hisbah, h.22.

25Ibn Taimiyah, al-Hisbah, h.22.
} 
tambahan dari dari harga yang pantas; perbuatan itu boleh dilakukan pengasa, babkan wajib untuk dilakukan.

Pemerintah selaku penguasa harus turun tangan melarang kekuatan monopoli, dengan tegas Ibn Taimiyah mengatakan:

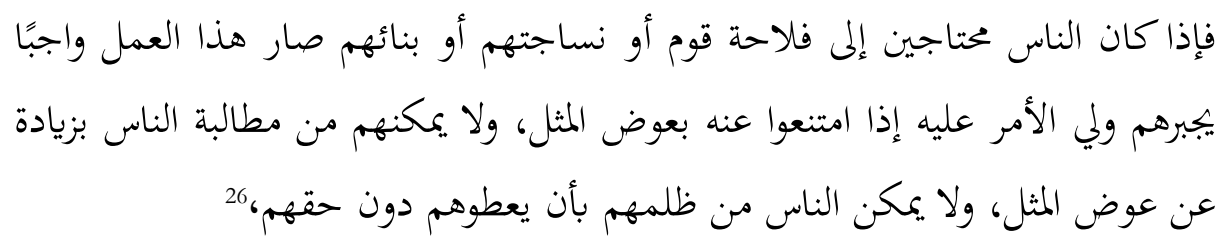

Maka apabila manusia butub kepada kebun (hasil kebun) mereka atau barang tenun mereka atau rumah (bahan bangunan) mereka ini menjadi amalan wajib pemerintah memaksa mereka apabila mereka menolak dengan harga yang pantas, dan tidak memberi peluang kepada mereka untuk meminta tambahan pada manusia (pembeli) dari harga yang pantas, dan tidak pula memberi peluang pada manusia (pembeli) untuk menzhalimi mereka dengan memberikan di bawah harga yang pantas.

Ibn Taimiyah membedakan dua jenis penetapan harga, yakni penetapan harga yang tidak adil dan cacat hukum serta penetapan harga yang adil dan sah menurut hukum. Penetapan harga yang tidak adil dan cacat hukum adalah penetapan harga yang dilakukan pada saat kenaikan harga-harga terjadi akibat persaingan pasar bebas, yakni kelangkaan supply atau kenaikan demand. ${ }^{27}$

\section{Kaitan Teori Ibn Taimiyah dengan Kewenangan Penguasa}

Berkaitan dengan teori mekanisme pasar yang digagas Ibn Taimiyah, bahwa penentuan harga diserahkan sepenuhnya pada mekanisme pasar. Fluktuasi harga terjadi bergantung dari suatu kekuatan penawaran dan permintaan yang bergulir secara alami. Maka dalam hal ini pemerintah tidak boleh turut campur, karena keterlibatan pemerintah dianggap zhalim terhadap pedagang, dan akan memperkeruh suasana pasar.

Hal ini sejalan dengan sikap Rasulullah SAW yang tidak mau mematok harga di saat harga-harga makanan melambung tinggi, lantaran itu terjadi secara alami menurut mekanisme pasar. Hadis tersebut selengkapnya berbunyi:

26Ibn Taimiyah, al-Hisbah, h.26.

${ }^{27}$ Adiwarman, Sejarah Pemikiran, h.368. 


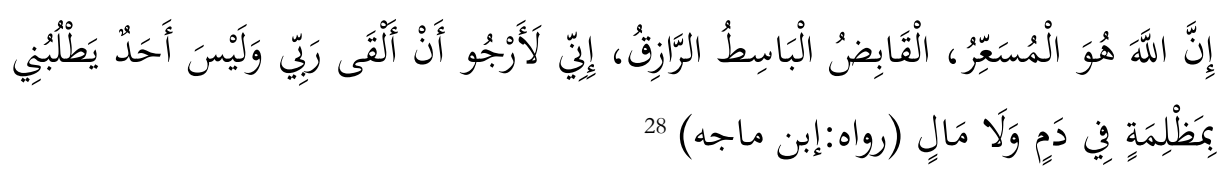

"Sesunggubnya, hanya Allah yang menetapkan harga, Dia yang menahan, Dia yang menghamparkan dan Dia yang memberi rizki. Sesunggubnya aku berharap dapat menemui Allah (di akhirat) tanpa seorang pun menuntut balasan kezaliman yang aku lakukan terhadap jiwa dan hartanya (karena menzalimi pedagang dengan menetapkan harga yang tentunya mengurangi lama untuk mereka)". (HR.Ibn Majah)

Asy-Syaukani, memahami hadis ini menjadi landasan bahwa penentuan harga itu haram atau suatu tindakan zhalim. Logikanya, manusia bebas menggunakan harta mereka, sedangkan penentuan harga menghambat hal itu. ${ }^{29}$ Teori Ibn Taimiyah ini, selayang pandang berbenturan dengan kewajiban umat Islam yang diperintahkan oleh Allah SWT untuk mentaati kewenangan penguasa sebagaimana pesan ayat 59 surat an-Nisa' berikut:

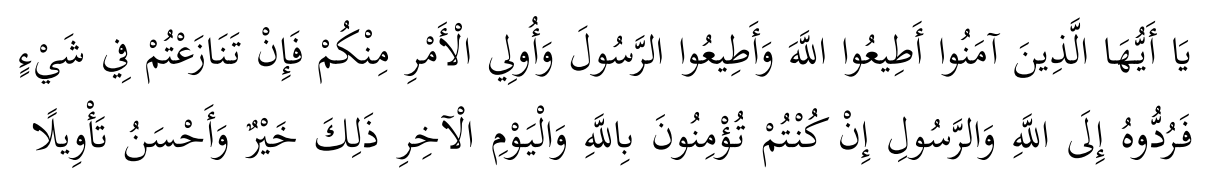

Hai orang-orang yang beriman, taatilah Allah dan taatilah Rasul (Nya), dan ulil amri di antara kamu. Kemudian jika kamu berlainan pendapat tentang sesuatu, Maka kembalikanlah ia kepada Allab (al-Qur'an) dan Rasul (sunnahnya),

${ }^{28}$ CD-ROOM, al-Makhtabah asy-Syamilah, Ibn Majah No Hadis. 2200.

${ }^{29}$ Yusuf Qardhawi, Norma dan Etika Ekonomi Islam, penerjemah Zainah Arifin dan Dahlian Husin, judul asli "Daurul Qiyam wal Akhlaq fil Iqtishadil Islam", (Jakarta: Gema Insani Press, 2006), Cet ke-6, 256. Berkaitan dengan batas maksimal seorang pedagang diperbolehkan mengambil keuntungan dapat disimak dari informasi hadis dari Urwah yang diriwayatkan oleh al-Bukharti mengatakan bahwa: Nabi SAW memberinya (Urwab) uang satu dinar untuke dibelikan kambing. Maka dibelikannya dua ekor kambing dengan uang satu dinar tersebut, kemudian dijualnya yang seekor dengan harga satu dinar. Setelah itu ia datang kepada Nabi SAW dengan membawa nang satu dinar dan seekor kambing. Kemudian beliau mendo'akan semoga jual belinya mendapat berkah. Dan seandainya uang itu dibelikan tanah, niscaya mendapatkan keuntungan juga. Lihat al-Makbtabah asy-Syamilah, al-Bukhari No Hadis. 3642. Berlandaskan hadis ini, maka tidak ada batas ketentuan yang baku untuk merup keuntungan dagang. Hanya saja perinsip hukum Islam tentang ta'awun (saling tolong-menolong). Dalam hal ini etika dan moral sangat berperan mematok harga yang wajar dan pantas. 
jika kamu benar-benar beriman kepada Allah dan hari kemudian. yang demikian itu lebih utama (bagimu) dan lebih baik akibatnya. (QS.4:59)

Menyikapi hal ini, dengan tetap memperhatikan kondisi pasar tidak sempurna, Ibn Taimiyah merekomendasikan bahwa bila penjual melakukan penimbunan dan menjual pada harga yang lebih tinggi dibandingkan dengan harga normal, padahal orang-orang membutuhkan barang ini, maka para penjual diharuskan untuk menjualnya pada tingkat harga ekuivalen. Perbuatan itu harus dan bahkan wajib dilakukan penguasa sebagimana katanya:

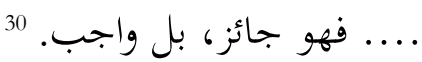

... perbuatan itu boleb dilakukan pengasa, babkan wajib untuk dilakukan.

Perbuatan penimbunan ini dinamakan oleh Ibn Taimiyah dengan ibtikar dan pelakunya disebut mubtakir, yaitu:

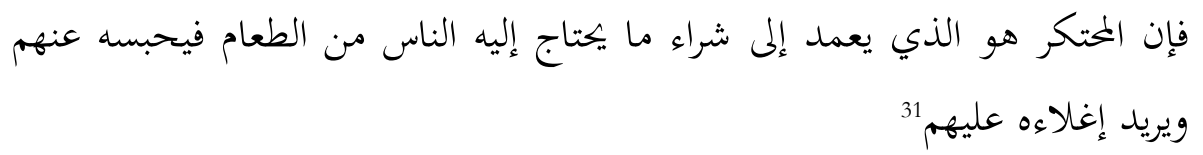

Maka sesunggubnya mubtakir adalah orang yang dengan sengaja membeli apa yang dibutubkan oleh orang banyak berupa makanan kemudian menimbunya dan bermaksut menaikekan harganya.

Nampaknya ibtikar dibatasi oleh Ibn Taimiyah pada makanan pokok. Lantaran itu merupakan kebutuhan dasar manusia, maka pemerintah berkewajiban menertibkan harganya. Penetapan larangan ibtikar khusus untuk makanan pokok sejalan dengan pendapat mazhab Hanafiyah, Syafi'iyah dan Hanabalah yang dianut oleh Ibn Taimiyah. Sementara itu, mazhab Maliki menetapkan bahwa objek ikbtikar mutlak apapun jenis barangnya. Ini sesuai dengan hikmah pelarangan ibtikar tidak merugikan orang banyak. ${ }^{32}$ Bahkan Fathi

${ }^{30}$ Ibn Taimiyah, al-Hisbah, h.22.

${ }^{31}$ Ibn Taimiyah, al-Hisbah, h.21. Pendapat jumhur ulama berdasarkan pada hadis dari Umar Ibn al-Khattab: "Barang siapa yang menimbun makanan pokok kaum muslimin, niscaya Allah akan menimpakan kepadanya penyakit kusta dan perdagangannya akan bangkrue" (HR. Ibn Majah). Lihat CR- ROOM, Ibn Majah, No Hadis. 2155.

${ }^{32}$ Erwandi Tarmizi, Harta Haram Kontemporer, (Bogor: Berkat Mulia Insani, 2012), Cet ke-2, h.163. 
ad-Duraini mengatakan bahwa ibtikar tidak saja menyangkut komoditi, tetapi juga manfaat suatu komoditi, dan bahkan jasa. Dengan syarat embargo yang dilakukan oleh para pedagang dan para memberi jasa ini membuat harga pasar tidak stabil. Dalam masalah jasa dia mencontohkan pada perusahaan transportasi atau buruh, ketika jasanya sangat diperlukan tidak mau memberikan jasanya. Terjadinya embargo ini harga jasa akan naik, saat terjadi kenaikan harga barulah mereka mulai menjajakan jasanya. ${ }^{33}$ Agaknya, untuk zaman sekarang, pendapat ini lebih memenuhi rasa keadilan baik bagi konsumen maupun produsen.

Secara kebetulan, konsep ini bersinonim dengan apa yang disebut harga yang adil. Lebih jauh, bila ada elemen-elemen monopoli (khususnya dalam pasar bahan makanan dan kebutuhan pokok lainnya), maka pemerintah harus turun tangan melarang kekuatan monopoli. ${ }^{34}$ Namun Ibn Taimiyah memboleh masyarakat untuk membeli pada pelaku ibtikar jika merupakan kebutuhan orang banyak, sebagaimana pernyataannya berbunyi:

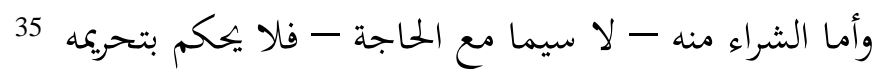

Adapun membeli dari pelaku ibtikar lantaran kebutuban maka tidaklah dihukum baram.

Pemerintah harus turun tangan melarang kekuatan monopoli, dengan tegas Ibn Taimiyah mengatakan:

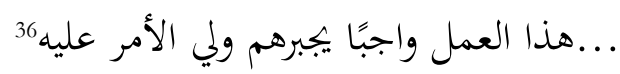

...ini menjadi amalan wajib pemerintah memaksa mereka apabila mereka...

Suatu kewajiban bagi penguasa bertindak tegas memaksa pelaku bisnis yang mematok harga secara wajar dan pantas. Penguasa tidak boleh lemah dengan memberi peluang kepada mereka untuk meminta tambahan harga. Ketegasan pun dituntut terhadap konsumen, menutup peluang mereka untuk memberikan harga di bawah harga yang pantas.

Ibn Taimiyah membedakan dua jenis penetapan harga, yakni penetapan harga yang tidak adil dan cacat hukum serta penetapan harga yang adil dan sah menurut hukum. Penetapan harga yang tidak adil dan cacat hukum adalah

${ }^{33}$ Nasrun Haroen, Fiqh Mu'amalah, (Jakarta: Gaya Media Pratama, 2000), Cet ke1, h.159-160.

${ }^{34}$ Munrokhim, Text Book, h.161.

35Ibn Taimiyah, Majmu', Jilid 15, h.133.

36Ibn Taimiyah, al-Hisbah, h.26. 
penetapan harga yang dilakukan pada saat kenaikan harga-harga terjadi akibat persaingan pasar bebas, yakni kelangkaan supply atau kenaikan demand. ${ }^{37}$

Pada kondisi terjadinya ketidak sempurnaan pasar, misalnya dalam kasus dimana komoditas kebutuhan pokok yang harganya naik akibat adanya manipulasi atau perubahan harga yang disebabkan oleh dorongan-dorongan monopoli. Maka dalam keadaan seperti inilah menurut Ibn Taimiyah, pemerintah harus menetapkan harga yang adil bagi penjual dan pembeli. ${ }^{38}$

Otoritas pemerintah dalam melakukan pengawasan harga harus dirundingkan terlebih dahulu dengan penduduk yang berkepentingan. Tentang ini, Ibn Taimiyah menjelaskan sebuah metode yang diajukan pendahulunya, Ibn Habib, bahwa pemerintah harus menyelenggarakan musyawarah dengan para tokoh perwakilan dan pasar. Yang lain juga diterima hadir, karenanya mereka harus diperiksa keterangannya. Setelah melakukan perundingan dan penyelidikan tentang transaksi jual beli, pemerintah harus secara persuasif menawarkan ketetapan harga yang didukung oleh para peserta musyawarah, juga penduduk semuanya. Jadi keseluruhannya harus sepakat dengan hal itu. ${ }^{39}$ Pendapat ini, dibenarkan oleh asy-Syaukani, Sementara itu, pemimpin harus menjaga kemaslahatan semua pihak. Ia wajib menyelasaikan masalah ini lewat ijtihad dan musyawarah antara dua pihak. ${ }^{40}$

Jadi jelas agaknya, bahwa pemikiran Ibn Taimiyah sangat memperhatikan keadaan pasar, bagaimana sikap perintah dalam mengawasi harga yang beredar dipasaran, penyelidikan, maupun menetapkan harga. Dalam kondisi ketidak sempuranaan pasar, maka pemerintah dianjurkan untuk mengadakan pengawasan terhadap harga yang beredar. Namun syarat dan ketentuan juga dijelaskan oleh Ibn Taimiyah, bahwa dalam mengadakan pengawasan, penyelidikan, maupun penetapan harga, harus dilakukan dengan musyawarah, dan seluruh oknum yang terkait harus menyepakati hasil musyawarah tersebut.

Pendapat Ibn Taimiyah tentang campur tangan penguasa apabila terjadi penyimpangan dan kesewenangan-wenangan harga, diamini oleh Yusuf alQaradhawy. Menurut Yusuf al-Qaradhawy sesuai dengan tugas dan tanggug jawabnya. Penguasa dapat membatasi keuntungan pedagang dengan batas tertentu, dari masing-masing komoditas yang berbeda-beda jenisnya. Mamun tindakan ini harus dilakukan melalui musyawarah dengan para ablu ra'yi wal

${ }^{37}$ Adiwarman, Sejarah Pemikiran, h.368.

${ }^{38}$ Nur, h. 236.

${ }^{39}$ Munrokhim, 161., lihat juga Euis Amalia, Sejarah Pemikiran, h.175.

${ }^{40}$ Yusuf Qardhawi, Norma dan Etika Ekonomi Islam, penerjemah Zainah Arifin dan Dahlian Husin, judul asli "Daurul Qiyam wal Akhlaq fil Iqtishadil Islam", (Jakarta: Gema Insani Press, 2006), Cet ke-6, h.256. 
bashirah (ahli pikir dan pemberi pertimbangan yang memiliki kualifikasi di bidangnya), sebagaimana dikemukakan oleh ulama-ulama terdahulu. ${ }^{41}$

Ibn Taimiyah berpendapat bahwa, penetapan harga diperlukan untuk mencegah manusia menjual makanan dan barang lainnya hanya kepada kelompok tertentu dengan harga yang ditetapkan sesuai keinginan mereka. Oleh karena itu, regulasi harga (fixed price policy) sangat mempermudah usaha mikro dalam menghadapi menipulasi pasar yang umumnya dilakukan oleh pengusaha besar. Kebijakan ini sering digunakan oleh pemerintah untuk melindungi sektor usaha mikro dari kehancuran. ${ }^{42}$

Juhaya mengomentari bahwa, pendapat Ibn Taimiyah menegaskan tentang tugas, fungsi, dan peran pemerintah adalah sebagai pelaksna amanat untuk kesejahtertaan rakyat yang ia sebut ada' al-amanah ila abliba. Pengelolaan negara serta sumber-sumber pendapatannya menjadi bagian dari seni olah negara (assiyasa'i syar'iyah) pengertian siyasah al-dusturiyyah maupun as-siyasa'i al-ma'liyyah (politik huku publik dan privat). Tampaknya Ibn Taimiyah menurut Juhaya, mempunyai kerangka pikir yang sejalan dalam pendapat yang menyatakan bahwa ekonomi syari'ah, baik sistem mamupun hukumnya merupakan bagian tidak terpisahkan dari sistem pemerintahan dan ketatanegaraan. ${ }^{43}$ Kebijakan pemerintah harus berpijak pada kemaslahatan umat, seperti bunyi kaidah:

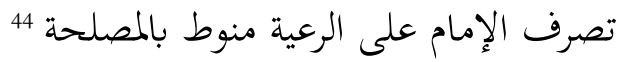

Kebijakan seorang pemimpin terhadap rakyatnya harus berorientasi pada kemaslabatan

\section{PENUTUP}

Para ulama klasik tidak hanya berkutat sebatas persoalan ibadah ritual saja, tetapi telah menaruh perhatian pada masalah perekonomian masyarakat. Bahkan diindikasikan teori-teori ekonomi konvensional modern merupakan adopsi dari hasil pemikiran mereka (Islam), salah satu dari mereka adalah Ibn Taimiyah.

Ia telah memberikan inspirasi tentang bagaimana persolan tentang mekanisme pasar, Ibn Taimiyah memiliki padangan yang jernih bagaimana

${ }^{41}$ Yusuf Qaradhawi, Fatwa-fatwa Kontemporer, penerjemah As'ad Yasin, judul asli "Hadyu al-Islam Fatawi Mu'ashirah", (Jakarta: Gema Insani Press, 1999), Jilid 2, Cet ke3: 620)

${ }^{42}$ Euis, Sejarah Pemikiran, h.175-176.

43Juhaya S. Praja, Ekonomi Syari'ah, (Bandung: Pustaka Setia, 2012), Cet ke-1, h.46.

${ }^{44}$ Asy-Syaikh Abdullah bin Sai'id Muhammad 'Ibady al-Lahjy al-Hadhuramy asySyihary, Idhah al-Qawa'id al-Fiqhiyah, (Kairo: al-Haromain, 1968), h.62. 
dalam sebuah pasar bebas, harga dipertimbangkan oleh kekuatan penawaran dan permintaan. Ibn Taimiyah memberikan penjelasan yang rinci tentang beberapa faktor yang mempengaruhi permintaan dan tingkat harga, yaitu permintaan masyarakat sangat bervariasi, tergantung pada jumlah barang yang tersedia, jumlah orang yang membutuhkan barang, besar dan kecilnya permintaan, kualitas pembeli, jenis uang yang digunakan sebagai alat pembayaran, kemampuan dan kredibilitas pembeli, dan biaya-biaya tambahan lainnya. Ia mengakui mekanisme pasar dengan syarat berjalan fair, wajar, suka sama suka dan tidak ada distorsi. Namun Ibn Taimiyah juga mengakui bahwa mekanisme pasar tidak selamanya berjalan sempurna, seringkali terjadi distorsi. Untuk itu ia memandang penting peranan pemerintah.

Sebuah negara berperan dalam pembangunan, khususnya pembangunan ekonomi. Solusi yang ditawarkan Ibn Taimiyah adalah negara hendaknya menjadi supervisor moralitas pembangunan untuk menyadarkan rakyatnya bahwa betapa pentingnya norma moral dan nilai etika sebagai asas pembangunan dan dapat mewujudkannya dalam kehidupan perekonomian.

Dengan demikian, terori mekanisme pasar Ibn Taimiyah tidak berseberangan dengan kewajiban mentaati pemerintah. Kerangka pikir ekonomi Ibn Taimiyah sejalan dalam pendapat yang menyatakan bahwa ekonomi syariah, baik sistem mamupun hukumnya merupakan bagian tidak terpisahkan dari sistem pemerintahan dan ketatanegaraan. Wallahu a'lam.

\section{DAFTAR PUSTAKA}

Amalia, Euis, Sejarah Pemikiran Ekonomi Islam, Jakarta : Grama Publishing, 1996 Cet ke-1

Azwar Karim, Adiwarman, Sejarah Pemikiran Ekonomi Islam, Jakarta: PT. RajaGrafindo Persada, 2006

__, Ekonomi Islam Suatu Kajian Kontempor, Jakarta: Gema Insani, 2007, Cet ke3

Abdullah, Boedi, Peradaban Pemikiran Ekonomi Islam Bandung: Pustaka Setia, 2010

Abd Sami', Usamah, al-Ibtikar fi Mizan asy-Syar'iyah al-Islamiyah, Iskandariyah: Dar al-Jami'ah al-Jadidah, 2007

Chamid, Nur, Jejak Langkah Sejarah Pemikiran Ekonomi Islam, Yogyakarta : Pustaka Pelajar, 2010, Cet. 1

CD-ROOM, al-Makbtabah asy-Syamilah 
http://www.hidayatullah.com/artikel/tsaqafah/read/2010/09/22/1309/hargapasar-menurut-ibnu -taimiyyah. html (diakses tanggal 21 April 2017)

Haroen, Nasrun, Fiqh Mu'amalah, Jakarta: Gaya Media Pratama, 2000, Cet ke-1

Al-Haritsi, Jaribah bin Ahmad, Fikib Ekonomi Umar bi Khathabia, penerjemah Asmuni Solihan Zamakhsyari, judul asli "Al-Fiqh al-Iqtishadi li Amiril Mukminin Umar bin Khaththab", Jakarta; Khalifa, 2006, Cet ke1

Islahi, Abdul Azim, Economic Concepts of Ibn Taimiyah, London: Islamic Foundation, 1988

Misanan, Munrokhim, dkk., Text Book Ekonomi Islam, Yogyakarta: Direktorat Perbankan Syariah Bank Indonesia DPbS BI \& Pusat Pengkajian dan Pengembangan Ekonomi Islam Universitas Islam Indonesia (P3EI UII)

Al-Maraghi, Abdulah Mustofa, Pakar-pakar Fiqh Sepanjang Sejarah, penerjemah Husein Muhammad, judul asli "Fath al-Mubin fi Tabaqat al-Usuliyyin", Yogyakarta: LKPSM, 2001

Qardhawi, Yusuf , Norma dan Etika Ekonomi Islam, penerjemah Zainah Arifin dan Dahlian Husin, judul asli "Daurul Qiyam wal Akhlaq fil Iqtishadil Islam", Jakarta: Gema Insani Press, 2006, Cet ke-6 ,Fatwa-fatwa Kontemporer, penerjemah As'ad Yasin, judul asli "Hadyu alIslam Fatawi Mu'ashirah”, Jakarta: Gema Insani Press, 1999, Jilid 2, Cet ke-3

S. Praja, Juhaya, Ekonomi Syari'ah, Bandung: Pustaka Setia, 2012, Cet ke-1

Sudarsono, Heri, Konsep Ekonomi Islam, Yogyakarta: Ekonisia, 2002

Umarudin, M, Ibn Taimiyah: Pemikiran dan Pembaharuan dalam Buku Mibrajan Ibn Taimizah, t.t: t.tp, t.th

Taimiyah, Taqi ad-Din Ahmad bin, Majmu' al-Tatwa, t.t: Dar al-Wafa' lil Kiba'ah wa an-Nasyar wa at-Tauzi', 2001, vol 8, Juz 15

—_, al-Hisbah fi al-Islam, Kairo: Dar Sya’b, 1976

Tarmizi, Erwandi, Harta Haram Kontemporer, Bogor: Berkat Mulia Insani, 2012, Cet ke-2

Muhammad, Asy-Syaikh Abdullah bin Sai'id 'Ibady al-Lahjy al-Hadhuramy asySyihary , Idhah al-Qawa'id al-Fiqhiyah, Kairo: al-Haromain, 1968 